\title{
Reproduction disorders in the benthic amphipod Monoporeia affinis: an effect of low food resources
}

\author{
Brita Sundelin $^{1, *}$, Rui Rosa ${ }^{2,3}$, Ann-Kristin Eriksson Wiklund ${ }^{1}$ \\ ${ }^{1}$ Stockholm University, Department of Applied Environmental Science (ITM), 10691 Stockholm, Sweden \\ ${ }^{2}$ Departamento de Inovação Tecnológica e Valorização dos Produtos da Pesca, IPIMAR, Avenida de Brasília, \\ 1449-006 Lisbon, Portugal
}

${ }^{3}$ Present address: Biological Sciences Center, University of Rhode Island, 100 Flagg Road, Kingston, Rhode Island 02881, USA

\begin{abstract}
The aim of the present study was to investigate the influence of food availability on reproduction by comparing the response of reproductive biomarkers of a deposit-feeding amphipod Monoporeia affinis in 2 Swedish lentic environments (Lake Vänern and Lake Vättern) differing in eutrophication level, during the period between 1995 and 2002. In ultraoligotrophic Lake Vättern, a very low fecundity (living eggs female ${ }^{-1}$ ) was found and severe embryo aberrations in terms of undifferentiated eggs $\left(\%\right.$ female $\left.{ }^{-1}\right)$, dead eggs ( $\%$ female $^{-1}$ ) and the percent of females with dead broods were recorded. A significant negative correlation between fecundity and (1) undifferentiated eggs and (2) dead eggs and broods were obtained in both lakes. Amphipods collected in Lake Vättern in 2001 showed significantly lower concentrations of lipids - mainly triacylglycerols (TAG) - and of fatty acids (FAs) than amphipods collected in the more eutrophic Lake Vänern. Dramatically increased spring bloom diatom abundance in Lake Vättern resulted in increased fecundity and lipid and fatty acid concentrations (namely monounsaturated fatty acids, MUFA) and decreased embryo aberrations. A significant relationship between fecundity and diatom biovolume in Lake Vänern and total algal biovolume in Lake Vättern was found. No other alga taxa influenced the fecundity. In Lake Vättern total algal biovolume was negatively related to undifferentiated eggs. MUFA and saturated fatty acids (SFAs) seem to be important for vitellogenesis and oogenesis and also constitute fuel during embryogenesis. Other environmental variables in bottom waters (i.e. oxygen, $\mathrm{pH}$ and temperature) and sediment organic content did not influence the reproduction variables. Our findings strongly suggest a relationship between embryo aberrations (e.g. undifferentiated eggs and dead broods) and low food resources.
\end{abstract}

KEY WORDS: Reproduction · Fatty acids · Embryo aberrations · Food deficiency · Monoporeia affinis

Resale or republication not permitted without written consent of the publisher

\section{INTRODUCTION}

Biomarkers on cellular, biochemical, or molecular levels are currently used within monitoring programs to provide early warning for future effects on higher organisational levels. Variables linked to reproduction combine the presumed higher sensitivity of loworganisation level biomarkers with the higher relevance attributed to variables that give more direct information on next-generation effects (Wu 2002). Sundelin and co-workers at ITM (described in Sundelin et al. 2008) have developed a method that allows for the detection of sediment contaminant effects on the reproduction of the deposit-feeding glacial relict amphipod Monoporeia affinis (Lindström). This method allocates a score to different reproduction variables, e.g. sexual maturation, fertilisation success, embryo aberrations (malformed, undifferentiated, dead eggs) and fecundity (Sundelin 1983, Sundelin \& Eriksson 1998, Sundelin et al. 2000, 2008). The bioassay thus detects next-generation effects that have strong repercussions at the population and ecosystem levels. This test has enabled observation of reproductive disturbances of the amphipod $M$. affinis in the Baltic Sea and has been adopted by ICES as a recommended technique for biological effect monitoring 
(www.ices.dk/reports/mhc/2004/WGBEC04.pdf). A recommended method should be able to discriminate between effects of contaminants and other environmental stressors in the field, a problem that is often overlooked in environmental monitoring. Despite the increasing use of biomarkers for assessing environmental toxicity, few studies examine the variability of biomarker response at uncontaminated sites, and studies of invertebrate response are even scarcer.

The importance of food quality and availability for growth and development in crustaceans has been extensively examined in laboratory experiments (e.g. Cruz-Riviera \& Hay 2000, von Elert \& Wolffrom 2001, Czeczuga et al. 2003). Despite some coverage of the effects of high-quality food availability on the fecundity of pelagic copepods in the field (Pond et al. 1996, Schmidt et al. 1998), few studies have provided data on fatty acids (FA) in benthic organisms (e.g. Hanson et al. 1985, Ghioni et al. 1996) or addressed the role of food quality for the efficiency of energy transfer in benthic communities (Gardner et al. 1990, Müller-Navarra et al. 2000). Effects on embryogenesis are even less well understood.

Different phytoplankton species differ in food quality, i.e. lipid concentration and FA composition and concentrations. Diatoms, cryptophytes and dinoflagellates are all regarded as high-quality food items for copepods (Brett \& Müller-Navarra 1997) compared to bacteria, bacterivorous cilates, cyanobacteria and chlorophytes (Ederington et al. 1995, Goedkoop et al. 2000, Boëchat \& Adrian 2006). Acartia tonsa increased fecundity 8-fold when fed diatoms compared to those fed ciliates. Of the measured FA, EPA (eicosapentaenoic acid) stood out by being abundant in diatoms, diatom-fed $A$. tonsa and their eggs and by being rare in ciliates, ciliate-fed copepods and their eggs (Ederington et al. 1995). However, despite the high fecundity (produced eggs female $^{-1}$ ) recorded in copepods fed by diatoms, some diatom species have been shown to affect egg hatching success and naupliar survival by synthesizing toxic aldehydes (Vargas et al. 2006 and references therein). We can find no studies on detrimental effects of diatoms to benthic amphipods. The advantage of diatoms compared to other high-quality algal taxa is mainly due to the fact that diatoms, normally dominating the spring bloom, can reach the sediment relatively intact and are regarded as high-quality food for deposit-feeding benthos (Ólafsson \& Elmgren 1997). Dinoflagellates seem instead to disintegrate in the water column and settle as unidentifiable detritus (Olli et al. 1998) and will contribute less to food resources for benthos. Whether diatoms or dinoflagellates dominate the spring bloom may thus greatly influence the input of carbon to deep water (Goedkoop \& Johnson 1996, Höglander et al. 2004 and references therein).
Diatoms are rich in essential polyunsaturated fatty acids (PUFA) of the linolenic (n-3) and linoleic (n-6) families. EPA (20:5n-3), docosahexaenoic acid (DHA, 22:6n-3), and arachidonic acid (ARA, 22:4n-6) are important indicators of high food quality in aquatic food webs (Glazier 2000, Müller-Navarra et al. 2000). PUFA ( $\geq 20 \mathrm{C}$ ) of the linolenic and linoleic families have also been proved to be important for growth and reproduction in planktonic crustaceans (Brett \& MüllerNavarra 1997), benthic copepods (Norsker \& Støttrup 1994, Ederington et al. 1995) and other benthic invertebrates (Vanderploeg et al. 1996).

The deposit-feeding amphipod Monoporeia affinis lives in both freshwater ecosystems, e.g. Lake Vänern and Lake Vättern, and the Baltic Sea. It is by far the most productive benthic invertebrate species with population densities up to 10000 ind. $\mathrm{m}^{-2}$. It occurs in soft-bottom substrates, ranging from sand to muddy sediments. It has been suggested that $M$. affinis and other deposit feeders of the Pontoporeiidae family feed non-selectively on sediment particles (Marzolf 1975, Lopez \& Elmgren 1989). However, despite a small fraction of algae in the gut, Goedkoop \& Johnson (2001) reported a strong correlation between yearly growth and diatom biovolume during the spring bloom. In the Baltic Sea, a significant correlation between fecundity (eggs female ${ }^{-1}$ ) and chlorophyll a (chl a) in the spring bloom was recorded (www.havet.nu/dokument/ Bv2000vitmarla.pdf). Thus, sedimented phytoplankton is supposed to be the most important food source, despite its minor fraction in the gut, while production of bacteria and meiofauna do not seem to cover the energy requirements of $M$. affinis (Goedkoop \& Johnson 1994). Also, experimental studies using radiotracers have shown that $M$. affinis rapidly assimilates the energy/nutrients in diatoms (Fitzgerald \& Gardner 1993, van de Bund et al. 2001).

Amphipods like Monoporeia affinis show an intermittent feeding strategy, and gut fullness is primarily observed after the spring phytoplankton bloom (Dermott \& Corning 1988, Quigley 1988). Later studies on Diporeia spp., a closely related North American freshwater species, have shown that gut fullness declines after the spring bloom, but increases later in the autumn (Guiguer \& Barton 2002). Between periods of phytoplankton blooms, the amphipods can cope without food or subsist on low-quality food by using energy stored as lipids, facilitated herein by the low temperatures in their soft-bottom habitat. The very low prespring-bloom ammonia excretion rate in $M$. affinis (Lehtonen 1994) further underlined the importance of stored lipids during periods of starvation.

Prior to the reproduction period, which starts in August, Monoporeia affinis, as well as Diporeia sp., accumulate high concentrations of lipids, which are trans- 
ferred to oocytes during sexual maturation. In decapod crustaceans, the amount of lipid reserves transferred from females to developing oocytes may exceed $60 \%$ of that remaining in the females (Herring 1973). Mating starts in November, in both freshwater environments and in the Baltic Sea, and lasts for $\sim 1$ mo. The embryogenesis of the amphipod $M$. affinis with direct development (lacking larval stages) is $\sim 2.5 \mathrm{mo}$, depending on temperature (Sundelin \& Eriksson 1998). The comparatively long embryogenesis indicates that this species needs to provide large energy reserves for the developing embryo. A minimum value of $\sim 20 \%$ lipids by dry weight has been suggested as necessary for initiating reproduction of $M$. affinis (Hill et al. 1992).

The main purpose of the present study was to examine the effects of food resources on reproduction of the amphipod Monoporeia affinis by comparing the reproductive biomarker response in environments differing in eutrophication level. The lipid level and FA profile and content in amphipods are assumed to reflect the composition and production of algae in spring bloom. The 2 largest Swedish lakes, Lake Vänern and Lake Vättern, were selected for the investigation.
Sampling. Lake Vättern was investigated in 1995, 1999, 2001 and 2002, while studies in Lake Vänern were carried out in 1999, 2001 and 2002. In Lake Vänern, 4 stations were investigated in all samplings, while in Lake Vättern 4 stations were studied in 1995, 5 stations in 1999 and 6 stations in 2001 and 2002 (Fig. 1, Table 1). Station 6 in Lake Vättern was added in 2001 to better cover the whole lake from south to north.

Juveniles and gravid females of Monoporeia affinis were collected by use of a sediment sled in January 1995, 1999, 2001 and 2002. The sled only allows semiquantitative samples, but enables greater samples of amphipods to be taken, thus facilitating statistical analyses. To optimize the efficiency of sampling the sled is swept along bottoms during $10 \mathrm{~min}$ with minimum ship speed. Wire length is 3 times the depth. The sediment was carefully sieved through a $1 \mathrm{~mm}$ mesh net. Juveniles (Age 1+) and gravid females were transferred to lake water of $+4^{\circ} \mathrm{C}$ before analyses of embryo development, according to Sundelin \& Eriksson (1998).

Sediment for analyses of organic content was sampled in 2001 by use of a modified Kajak core sampler.

\section{MATERIALS AND METHODS}

Study area. Both Lake Vänern and Lake Vättern have been moderately contaminated by industrial discharges, e.g. wastewater from pulp mills and municipal activities, but differ in the eutrophication level (data obtained from http://info1.ma. slu.se). Lake Vänern is more eutrophic (annual mean secchi depth was $4.5 \mathrm{~m}$ in the period from 1971 to 2002) than the ultraoligotrophic Lake Vättern (annual mean secchi depth was $11 \mathrm{~m}$ in the period from 1971 to 2002). Lake Vänern has a higher concentration of chl a (annual mean in spring bloom from 1998 to 2001 at Stations 2, 3 and 4 was $3.1 \mathrm{mg} \mathrm{m}^{-3}$ ) than Lake Vättern (annual mean spring bloom from 1998 to 2001 at Stations 2 and 6 was $1.2 \mathrm{mg}$ $\mathrm{m}^{-3}$ ). Lake Vänern and Lake Vättern have mean depths of 27 and $40 \mathrm{~m}$, respectively. Mean abundance of Monoporeia affinis on studied stations in the period from 1998 to 2001 was slightly higher in Lake Vänern (2000 to 3000 ind. $\mathrm{m}^{-3}$ ) than in Lake Vättern (1750 to 2500 ind. $\mathrm{m}^{-3}$ ), but showed great variability for reasons that remain to be established. A recent study suggests food resources as the limiting factor (Goedkoop \& Johnson 2001).

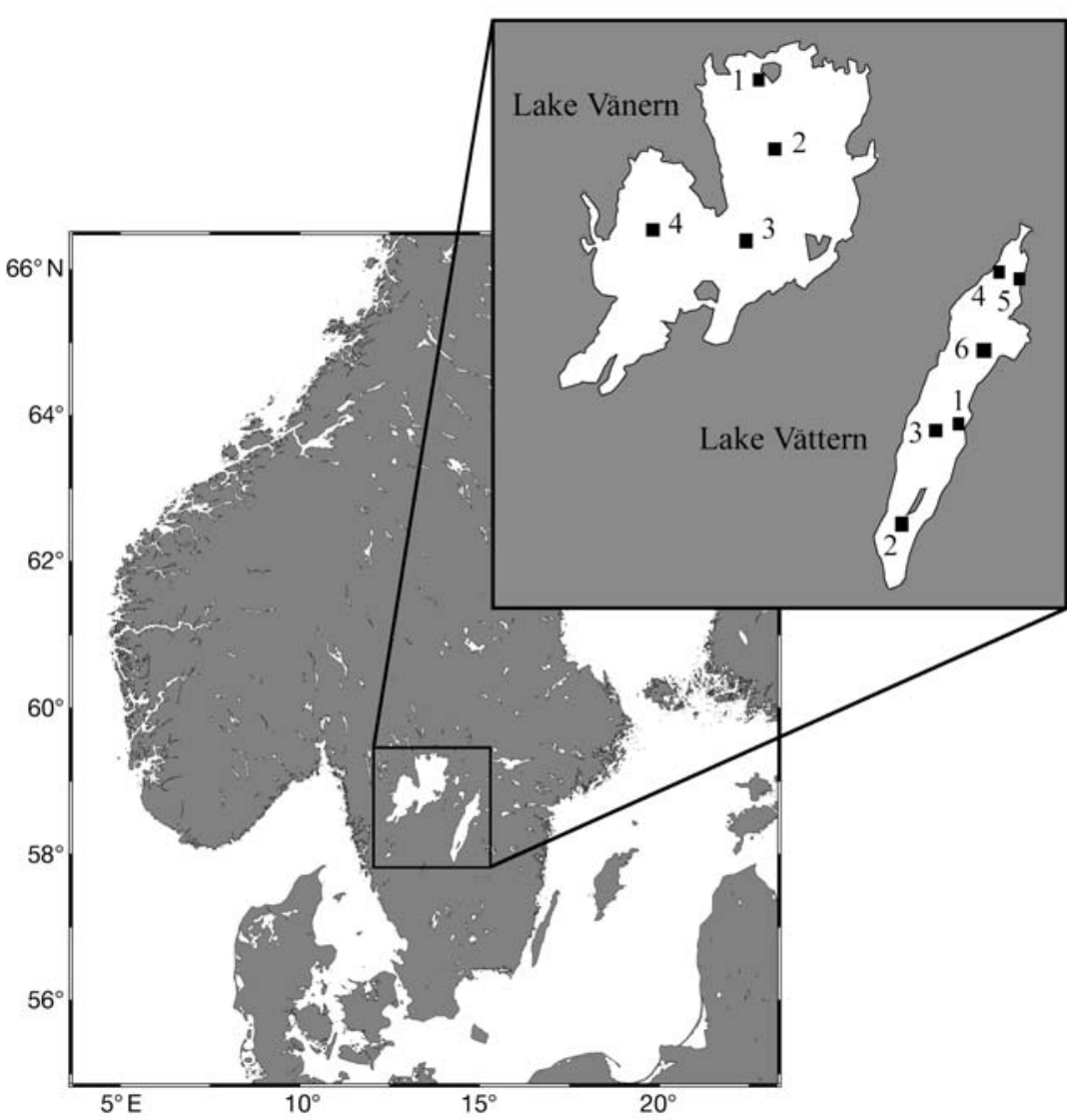

Fig. 1. Study area. Lake Vänern was investigated during 3 yr (1999, 2001 and 2002). Lake Vättern was investigated in 1995 (Stns 1, 2, 3 and 4), 1999 (Stns 1, 2, 3, 4 and 5), and 2001 and 2002 (Stns 1, 2, 3, 4, 5 and 6) 
Table 1. Depth and organic content (measured as loss on ignition), in sediment from investigated stations in Lake Vänern and Vättern and number of gravid females sampled and analysed at the stations in each given year

\begin{tabular}{|c|c|c|c|c|c|c|}
\hline \multirow{2}{*}{ Stn } & \multirow{2}{*}{$\begin{array}{l}\text { Depth } \\
\text { (m) }\end{array}$} & \multirow{2}{*}{$\begin{array}{c}\text { Organic } \\
\text { content }(\%)\end{array}$} & \multirow[b]{2}{*}{1995} & \multicolumn{2}{|c|}{ Gravid females (n) } & \multirow[b]{2}{*}{2002} \\
\hline & & & & 1999 & 2001 & \\
\hline \multicolumn{7}{|c|}{ Lake Vänern } \\
\hline 1 & 42 & 9.3 & - & 20 & 2 & 7 \\
\hline 2 & 77 & 9.7 & - & 90 & 30 & 16 \\
\hline 3 & 60 & 8.9 & - & 33 & 40 & 24 \\
\hline 4 & 77 & 7.5 & - & 104 & 81 & 19 \\
\hline \multicolumn{7}{|c|}{ Lake Vättern } \\
\hline 1 & 95 & 10.6 & 57 & 17 & 83 & 72 \\
\hline 2 & 90 & 6.4 & 15 & 26 & 108 & 62 \\
\hline 3 & 35 & 7.9 & 11 & 39 & 57 & 58 \\
\hline 4 & 20 & 8.4 & 15 & 18 & 31 & 9 \\
\hline 5 & 98 & 9.5 & - & 21 & 67 & 111 \\
\hline 6 & 98 & 9.6 & - & - & 48 & 70 \\
\hline
\end{tabular}

Surface sediment $(0$ to $1 \mathrm{~cm})$ was sliced and analysed for organic content, measured as loss on ignition.

Biological analyses. All collected females (see Table 1) were analysed in terms of reproduction variables. The analysis of Monoporeia affinis embryos is preferably carried out in the later embryogenesis (the end of January). In the last stages of embryo development even small changes from normal development are discernable. In the embryo analysis, eggs and embryos were carefully removed from the living female and analysed, using a stereomicroscope (80× magnification, Leica MZ12). Embryo aberrations such as malformed embryos, unfertilized/undeveloped eggs (henceforth called undifferentiated eggs), dead eggs and dead broods were scored (Fig. 2a,b) (see Sundelin \& Eriksson 1998, Sundelin et al. 2008). Embryos are classified as malformed when they show various degrees of deformities of eyes, legs, or midgut, and/or membrane dysfunction, which means that lipids leak out through the membranes or that water content in embryos increases causing oedema. Undifferentiated eggs are either unfertilised or have ceased in development before gastrulation (Fig. 2). Single dead eggs or dead broods, where part of the brood (Fig. 2b) or the whole brood had died early in embryogenesis and single eggs are unidentified, are related to increased temperature before mating and deficiency (Eriksson Wiklund \& Sundelin 2001). Also in situ females with dead broods are related to oxygen deficiency, in terms of oxygen concentrations in bottom water (Eriksson Wiklund \& Sundelin 2004). All these described embryo aberrations are lethal.

Fifty broods from each sampling year were spread across stations and analysed independently by 2 persons in order to minimise the risk of subjective assessment. The females were analysed in terms of fecundity (living eggs female ${ }^{-1}$ ), occurrence of parasites and other visible deviations from normal appearance.

Lipid classes and FA analyses. In order to evaluate the nutritional condition of amphipods, juveniles, on account of size estimated to reproduce next autumn,
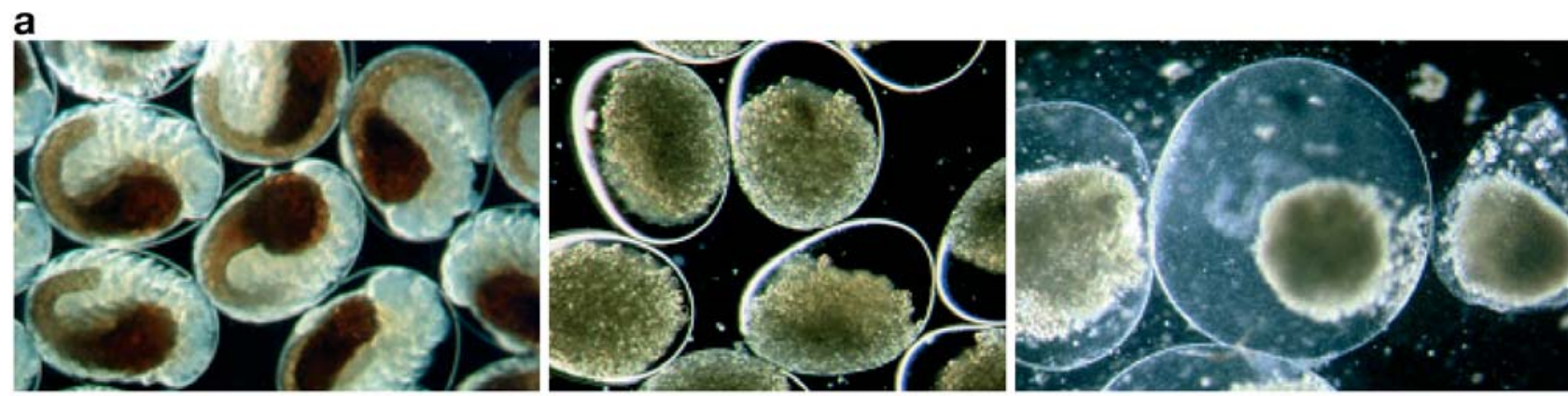

b

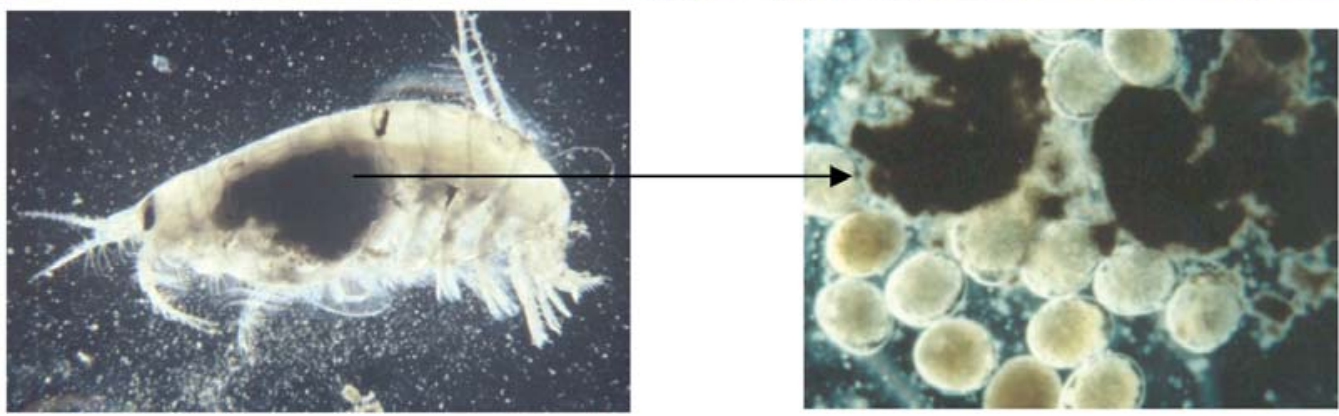

Fig. 2. Monoporeia affinis. (a) Illustrations of normal embryos (left panel), undifferentiated eggs (middle panel) and dead eggs (right panel). (b) Female with a dead brood (left panel) and the brood with unidentified dead eggs (the dark areas) 
were analysed in terms of lipids and FAs in 2001 and 2002. It is worth noting that due to insufficient samples, it was not possible to make the comparison between lipid composition of adult gravid females and their reproductive variables, since all gravid females were used in the embryo analyses. The lipid content of the female after dissecting the brood is irrelevant. The developing embryos catabolise their stored energy reserves, mainly monounsaturated fatty acids (MUFA) (Morais et al. 2002, Rosa et al. 2005, 2007), which leads to a continuous reduction in embryo lipid content. Thus, analyses of gravid females in late embryogenesis are not relevant either. Analyses of females in early oogenesis would have been the most optimal strategy, but increases the cost for sampling tremendously.

Before analyses, the amphipods were stored for 2 mo in $-80^{\circ} \mathrm{C}$ to eliminate the risk of oxidation of lipids and FA (Goedkoop et al. 2000). Twenty animals were randomly sampled and pooled together, and homogenized before analyses. Duplicate samples from each station in Lake Vättern and Vänern were analysed.

Total lipids were extracted according to Bligh \& Dyer (1959). Lipid classes were separated in a gradient high-performance liquid chromatography (HPLC) system, equipped with a Jasco PU 980 pump in combination with a Jasco LG-980-2 gradient controller and a GASTORR GT-104 degassing system. Separation was done following the method described by Nordbäck et al. (1998), in a $250 \times 4.6 \mathrm{~mm}^{2}$ i.d. (inner diameter) column packed with $5 \mu \mathrm{m}$ YMC PVA-sil, and the detection was accomplished with a Sedex Model 65 evaporative light-scattering detector. A Jasco AS 950-10 autoinjector was used with an injection volume of $20 \mu \mathrm{l}$. The detector signals were processed by a Borwin Version 1.2 chromatography software.

Determination of the FA profile was based on the experimental procedure of Lepage \& Roy (1986), modified by Cohen et al. (1988). The FA methyl esters were analysed in a Varian 3400 gas chromatograph, equipped with an auto-sampler and fitted with a flame ionization detector (FID). The separation was carried out with helium as carrier gas in a fused silica capillary column Chrompack CPSil/88 (50 $\mathrm{m} \times 0.32 \mathrm{~mm}$ i.d.), programmed from 180 to $200^{\circ} \mathrm{C}$ at $4^{\circ} \mathrm{C} \mathrm{min}{ }^{-1}$, held for $10 \mathrm{~min}$ at $200^{\circ} \mathrm{C}$ and heated to $210^{\circ} \mathrm{C}$ for $14.5 \mathrm{~min}$, with a detector at $250^{\circ} \mathrm{C}$. A split injector $(100: 1)$ at $250^{\circ} \mathrm{C}$ was used. FA methyl esters were identified by comparison of their retention time with those of chromatographic Sigma standards. Since the response factor of the FID depends mainly on the carbon number of compounds, the peaks of compounds, for which no standard was available, were calibrated relative to another compound of the same carbon number. Peak areas were determined using the Varian software, and the FA 21:0 was used as an internal standard.
Environmental conditions. Environmental biotic parameters in terms of biovolume of algae $\left(\mathrm{mm}^{3} \mathrm{l}^{-1}\right)$, and abiotic parameters, i.e. oxygen concentrations $\left(\mathrm{mg} \mathrm{l}^{-1}\right), \mathrm{pH}$ and temperature in bottom waters $(90 \mathrm{~m}$ depth) were taken from the environmental monitoring data base at the Department of Environmental Assessment at the Swedish University of Agricultural Sciences, Uppsala (http://info1.ma.slu.se) and correlated to reproduction variables of Monoporeia affinis, in Lakes Vänern and Vättern.

Statistical analyses. For analyses of reproductive variables, Kruskal-Wallis analysis was used to test the effect of years and stations within each lake (data from 1995, 1999, 2001 and 2002). Mann-Whitney U-test was used for comparison of reproductive variables between Lakes Vänern and Vättern (data from 1995, 1999, 2001 and 2002). The Mann-Whitney $U$-test was also used for analyses of FA composition between Lakes Vänern and Vättern in 2001 and 2002. Comparisons between lakes and years (2001 and 2002) regarding lipid and FA concentrations were evaluated by Student's $t$-test, except 16:1n-7, which was evaluated by the MannWhitney $U$-test due to inhomogenous variances. The relationships between fecundity, organic content and embryo aberrations, in terms of malformed and undifferentiated eggs and dead eggs and broods, in both lakes (pooled data), were investigated by correlation analyses (non-parametric Spearman correlation coefficients). The relationship between environmental parameters (available at http://info1.ma.slu.se), i.e. oxygen concentrations $\left(\mathrm{mg} \mathrm{l}^{-1}\right)$ and temperature in bottom waters, biovolume of total algae and diatoms in spring bloom $\left(\mathrm{mm}^{3} \mathrm{l}^{-1}\right)$ and reproductive variables (fecundity and embryo aberrations) in Lakes Vättern and Vänern were also investigated by correlation analyses (nonparametric Spearman correlation). Environmental data were available for 2 stations in Lake Vättern (2 and 6) and 3 stations in Lake Vänern $(2,3,4)$ and were correlated to amphipod reproductive variables at the respective stations.

\section{RESULTS}

\section{Environmental conditions}

Total biovolume and biovolume of major algal taxa are replotted in Fig. 3 from the IMA website (http:// info1.ma.slu.se). The biovolume of diatoms in the spring bloom of 2001 was 3-fold the average value measured in the last decades. The highest annual mean value since 1978 was measured in Lake Vättern in 2001. This increase was not reflected in other dominating phytoplankton groups, i.e. Chrysophycae (golden algae), Cryptophycae, Dinophycae or Cyano- 

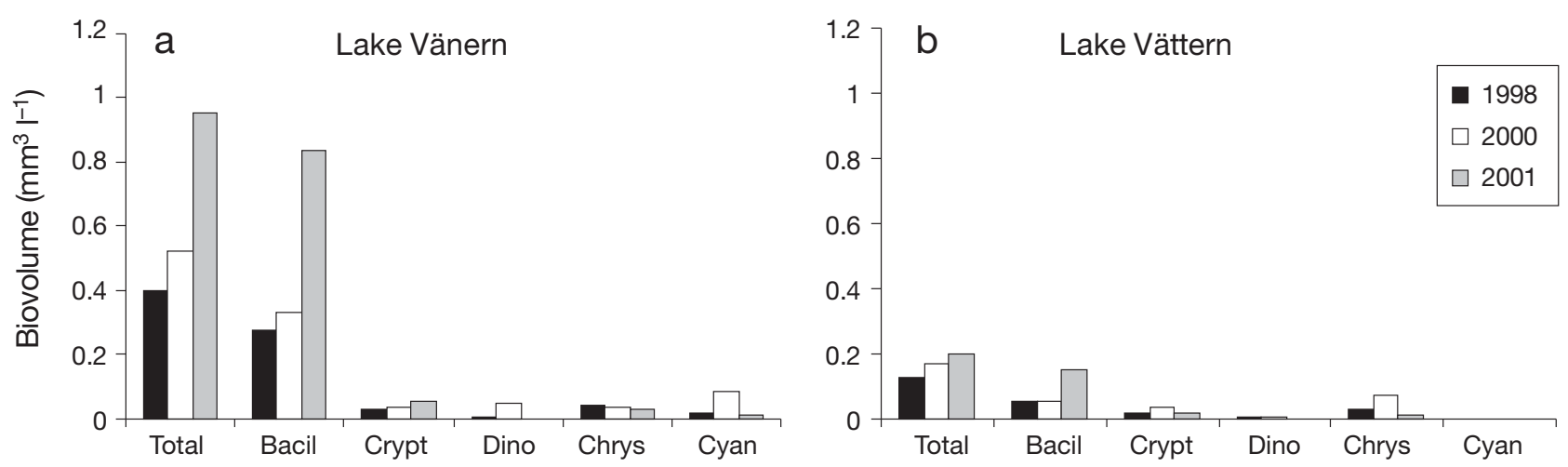

Fig. 3. Biovolume of major algal taxa in the spring bloom (April to June) of 1998, 2000 and 2001, the production seasons governing the amphipod reproductive success analysed in January the following year. Bacil: Bacillariophycea; Crypt: Cryptophycae; Dino: Dinophycae; Chrys: Chrysophycae; Cyan: Cyanophycae. (a) Data (see http://info1.ma.slu.se/db.html) from Lake Vänern are based on a mean value for Stns 2, 3 and 4. (b) Data from Lake Vättern are based on a mean value for Stns 2 and 6

phycae, which means that the fraction of diatoms increased. In reality, e.g., Cryptophycae and Chrysophycae decreased in biovolume in 2001. The increase in diatoms was seen in both lakes (Fig. 3).

Abiotic parameters in terms of $\mathrm{pH}$ and oxygen concentrations in bottom waters (90 m depth) did not change during the investigation period (http://info1. ma.slu.se), and very high oxygen concentrations were measured in Lake Vättern (10 to $15 \mathrm{mg} \mathrm{l}^{-1}$ ). Small changes in bottom water temperature $(90 \mathrm{~m}$ depth) during autumn (the most critical period for reproduction effects in Monoporeia affinis) were recorded, and slightly higher temperature was recorded at Stn 2 in 2001 compared to 2000, while no difference was recorded at Stn 6 between 2000 and 2001 (Table 2).

\section{Female abundance}

The relative abundance based on semi-quantitative sled sampling of gravid females was higher in Lake Vättern in 2001 and 2002 as compared to 1999, while the opposite situation was recorded in Lake Vänern, where a lower number of gravid females was sampled in 2001 and particularly in 2002 (Table 1).

\section{Fecundity}

A significant difference in the amphipod fecundity (eggs female ${ }^{-1}$ ) between lakes was recorded in the investigation period from 1999 to 2002, Lake Vättern showing lower fecundity ( $\mathrm{p}<0.0001$, Mann-Whitney). Extremely low fecundity was recorded in Lake Vättern in the period from 1995 to 2001 (6.5 to 15.2 eggs female ${ }^{-1}$ ), while fecundity was doubled in 2002 (Fig. 4).
Table 2. Temperature data $\left({ }^{\circ} \mathrm{C}\right)$ in bottom waters from 1998 to 2001 in Lake Vättern at Stn 2 (http://info1.ma.slu.se/ma/ www_ma.acgi\$Station?ID=Intro\&S=194) and at Stn 6 (http:// info1.ma.slu.se/ma/www_ma.acgi\$Station?ID=Intro\&S=579)

\begin{tabular}{|lllc|}
\hline \multirow{2}{*}{ Year } & Date & \multicolumn{2}{c|}{ Temperature } \\
& & Stn 2 & Stn 6 \\
\hline \multirow{2}{*}{1998} & 22 Apr & 2.6 & 2.2 \\
& 19 May & 3.8 & 3.8 \\
& 14 Jul & 4.1 & 4.5 \\
& 11 Aug & 4.2 & 4.6 \\
2000 & 11 Apr & 2.5 & 2.3 \\
& 23 May & 3.9 & 4.0 \\
& 18 Jul & 4.7 & 5.2 \\
& 9 Aug & 4.7 & 5.9 \\
& 18 Apr & 2.5 & 2.3 \\
& 22 May & 3.9 & 3.9 \\
& 17 Jul & 4.6 & 5.0 \\
& 18 Sep & 5.9 & 5.8 \\
\hline
\end{tabular}

However, in 2002, increased fecundity was also recorded in Lake Vänern, maintaining the difference between the lakes ( $p<0.001$, Mann-Whitney) (Fig. 4). Fecundity was positively related to total quantity of algae, measured as $\mathrm{mm}^{3} \mathrm{l}^{-1}\left(\mathrm{p}<0.005, \mathrm{r}_{\mathrm{s}}=0.943\right.$, nonparametric Spearman correlation analysis) in Lake Vättern and diatom volume $\left(\mathrm{p}<0.025, \mathrm{r}_{\mathrm{s}}=0.733\right.$, Spearman correlation analyses; see Fig. 3) in Lake Vänern. No other algal groups influenced the fecundity, but a strong correlation between total biovolume and diatom volume was recorded in both lakes (data from both lakes, $\mathrm{p}<0.0001, \mathrm{r}_{\mathrm{s}}=0.946$, non-parametric Spearman correlation analysis), reflecting the importance of diatoms for total increase. No correlations between fecundity, sediment organic content, oxygen and temperature in bottom waters were recorded $(\mathrm{p}>$ 0.05 , non-parametric Spearman correlation analysis). 

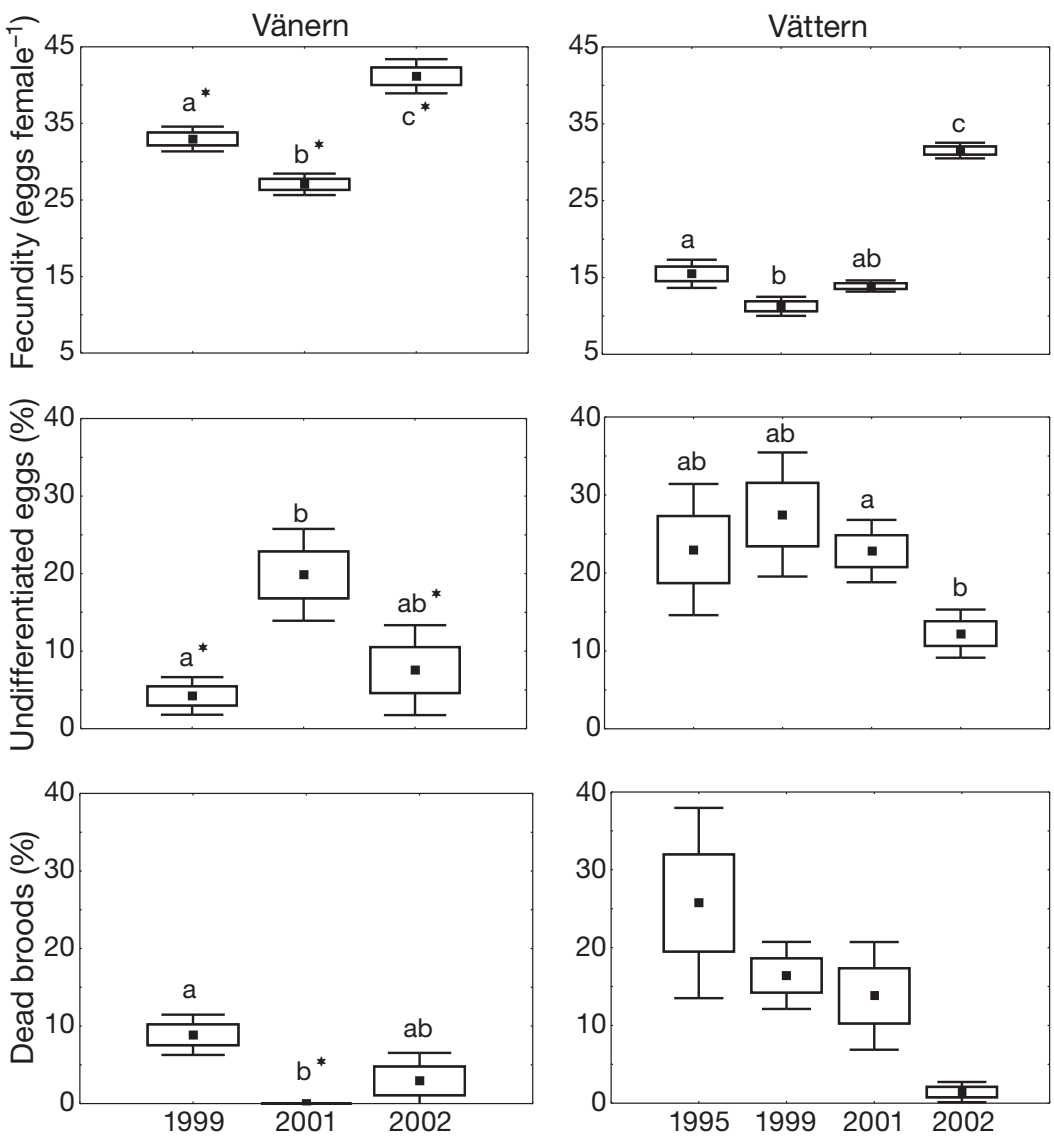

Fig. 4. Monoporeia affinis. Fecundity (eggs female ${ }^{-1}$ ), frequency of undifferentiated eggs (\%) and frequency of dead broods (\%) in females from Lake Vänern (between 1999 and 2002) and Lake Vättern (between 1995 and 2002). Data are mean values (black square) at the different stations (4 in Lake Vänern and 6 in Lake Vättern), SEs (boxes) and 0.95 CIs (whiskers). Different letters indicate significant differences (Kruskal-Wallis test, $p<0.05$ ) between years in each lake. ${ }^{*}$ Significant differences (Mann-Whitney test, $\mathrm{p}<0.05$ ) between lakes in that year

between stations was recorded during the sampling period. There was a significant correlation between undifferentiated eggs and fecundity (pooled data from both lakes, $\mathrm{p}<0.001, \mathrm{r}_{\mathrm{s}}=$ -0.649, non-parametric Spearman correlation analysis), and undifferentiated eggs were negatively related to total algal volume $\left(\mathrm{p}<0.0001, \mathrm{r}_{\mathrm{s}}=\right.$ -0.986, non-parametric Spearman correlation analysis) in Lake Vättern. No relationship between undifferentiated eggs and algal volume was recorded in Lake Vänern ( $p>0.05$, non-parametric Spearman correlation analysis). Oxygen and temperature in bottom waters did not influence the undifferentiated eggs in either lake $(p>0.05$, non-parametric Spearman correlation analysis).

\section{Dead broods and dead eggs}

Females carrying dead broods differ between the lakes, being more frequent in Lake Vättern from 1999 to 2002 ( $\mathrm{p}<0.05$, Mann-Whitney; Fig. 4). No difference was recorded between stations in either lake (Figs. 2b \& 4). Single dead eggs (\% female $^{-1}$ ) did not differ between the lakes in the period from 1999 to 2002 (Fig. 2a), while single years differ between the lakes, dead eggs occurring more frequently in Lake Vättern in 2001 ( $\mathrm{p}<0.01$, Mann-Whitney). No

\section{Undifferentiated eggs}

Very high frequencies of undifferentiated eggs (\% female $^{-1}$ ) of Monoporeia affinis were recorded in Lake Vättern during the investigation period (Figs. 2a \& 4). Comparatively high frequencies were recorded also in Lake Vänern in 2001, but a comparison between lakes showed a higher frequency of undifferentiated eggs in Lake Vättern in the period from 1999 to 2002 ( $p<0.05$, Mann-Whitney; Fig. 4). Females with undifferentiated eggs showed high mortality during handling, and the undifferentiated eggs ruptured easily on examination due to impaired membranes. In 2002, the frequency of undifferentiated eggs decreased in Lake Vättern ( $\mathrm{p}<$ 0.02, Kruskal-Wallis; Fig. 4) and the robustness for handling of females and eggs increased. Undifferentiated eggs increased between 1999 and 2000 in Lake Vänern ( $<<0.0001$, Kruskal-Wallis; Fig. 4), whilst no difference differences between stations were found in either lake. Significant correlations between fecundity and dead eggs and dead broods were found $\left(\mathrm{p}<0.01, \mathrm{r}_{\mathrm{s}}=\right.$ -0.628 and $r_{s}=-0.60$, respectively, non-parametric Spearman correlation analysis). Production of algae and abiotic water parameters such as oxygen and temperature in bottom waters did not influence dead eggs or dead broods in the females in either lakes ( $\mathrm{p}>0.05$, non-parametric Spearman correlation analysis).

\section{Malformed eggs and embryos}

Malformed eggs and embryos ( $\%$ female ${ }^{-1}$ ) did not differ between the lakes in the sampling period. No correlation between fecundity and malformed embryos was found ( $p>0.05$, non-parametric Spear- 
man correlation analysis). Production of algae and abiotic water parameters such as oxygen and temperature in bottom waters did not influence the malformation rate in either Lake Vättern or Lake Vänern ( $p>0.05$, nonparametric Spearman correlation analysis).

\section{Nutritional condition of Monoporeia affinis juveniles}

Extremely low lipid concentrations were measured in Lake Vättern amphipods in 2001. Concentrations in amphipods were just half of the values in Lake Vänern, and a significant difference between lakes was recorded $(p<0.002, d f=6, t$-test; Fig. 5). No difference between stations was recorded. In 2002, increased lipid concentrations in amphipods were found particularly in Lake Vättern, and, when compared to Lake Vänern, only total lipids and triacylglycerols (TAG) showed significantly lower concentrations ( $\mathrm{p}<0.003$, df $=4, t$-test). Phospholipids and other lipid classes did not differ between lakes $(\mathrm{p}>0.05)$.

Similarly to lipids, composition of FAs in amphipods differed between lakes in 2001, whilst no changes were recorded in 2002 (Table 3), no difference between stations being recorded. The percentages of SFA (satuarated fatty acids) and MUFA were considerably higher in Lake Vänern in 2001. The percentages of the PUFAs DHA and ARA were higher in Lake Vättern in 2001 ( $p<0.0001$ and $p<0.003$, respectively, Mann-Whitney), while EPA did not differ between lakes ( $p>0.05$ ).

Since FAs constitute about $80 \%$ of lipids, concentrations of total FA consequently correlate to lipid concentrations, lower values being recorded in Lake Vättern in $2001(\mathrm{p}<0.0001, \mathrm{df}=$ $7, t$-test; Fig. 6), and significant differences between lakes were recorded $(\mathrm{p}<0.0001, \mathrm{df}=8, t$-test). The largest difference between lakes was attributed to SFA and MUFA, though concentrations of PUFA also differed significantly between the lakes $(\mathrm{p}<$
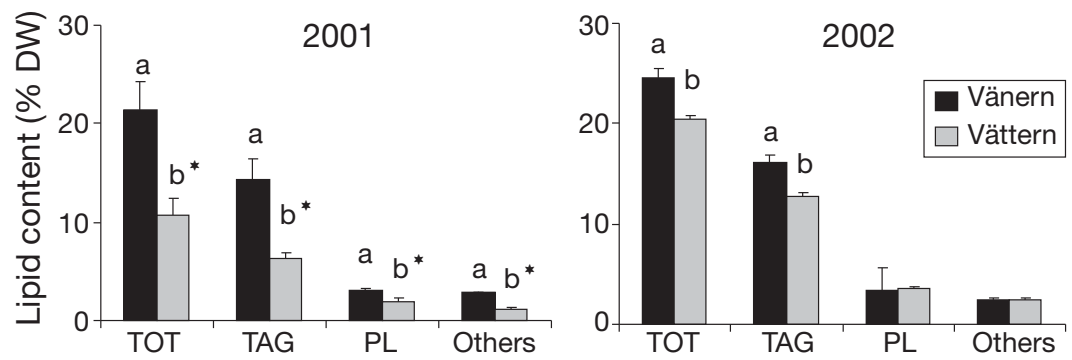

Fig. 5. Monoporeia affinis. Concentrations (\% dry wt) of total lipids and lipid classes in M. affinis collected in Lake Vänern and Lake Vättern in 2001 and 2002. TOT: total; TAG: triacylglycerols; PL: phospholipids. Data are means (+SD) of pooled amphipod samples from 4 stations in each of Lake Vänern and Lake Vättern. Different letters indicate significant differences $(t$-test, $\mathrm{p}<0.05)$ between

lakes. ${ }^{*}$ Significant differences $(t$-test, $\mathrm{p}<0.05)$ between years in that lake

Table 3. Monoporeia affinis. Relative fatty acid composition (\% total fatty acids) in juvenile amphipods collected in Lake Vänern and Lake Vättern during 2001 and 2002. Data are mean \pm SD of 4 to 6 replicate samples

\begin{tabular}{|c|c|c|c|c|}
\hline \multirow[t]{2}{*}{ Fatty acids } & \multicolumn{2}{|c|}{ — Lake Vänern $ـ$} & \multicolumn{2}{|c|}{ —— Lake Vättern } \\
\hline & 2001 & 2002 & 2001 & 2002 \\
\hline $12: 0$ & $0.14 \pm 0.02$ & $0.11 \pm 0.02$ & $0.19 \pm 0.15$ & $0.08 \pm 0.03$ \\
\hline $14: 0$ & $5.78 \pm 0.76$ & $6.33 \pm 0.16$ & $4.22 \pm 1.73$ & $6.51 \pm 0.54$ \\
\hline $15: 0$ & $0.19 \pm 0.03$ & $0.22 \pm 0.04$ & $0.28 \pm 0.03$ & $0.21 \pm 0.03$ \\
\hline $16: 0$ & $11.58 \pm 1.31$ & $11.34 \pm 1.64$ & $9.10 \pm 1.20$ & $9.51 \pm 3.22$ \\
\hline $17: 0$ & $1.69 \pm 0.98$ & $1.64 \pm 0.93$ & $0.64 \pm 0.35$ & $2.10 \pm 0.55$ \\
\hline $18: 0$ & $1.31 \pm 0.16$ & $1.22 \pm 0.17$ & $1.05 \pm 0.30$ & $1.06 \pm 0.41$ \\
\hline 19:0 & $0.09 \pm 0.02$ & $0.09 \pm 0.01$ & $0.07 \pm 0.02$ & $0.10 \pm 0.03$ \\
\hline 20:0 & $0.02 \pm 0.01$ & $0.05 \pm 0.02$ & $0.05 \pm 0.03$ & $0.05 \pm 0.02$ \\
\hline $22: 0$ & $0.03 \pm 0.01$ & $0.04 \pm 0.02$ & $0.08 \pm 0.05$ & $0.01 \pm 0.00$ \\
\hline$\Sigma$ Saturated & $20.83 \pm 1.65$ & $21.04 \pm 1.90$ & $15.69 \pm 1.90$ & $19.63 \pm 4.47$ \\
\hline Iso $14: 0$ & $0.08 \pm 0.01$ & $0.10 \pm 0.01$ & $0.10 \pm 0.05$ & $0.09 \pm 0.00$ \\
\hline Anteiso 14:0 & $0.08 \pm 0.01$ & $0.07 \pm 0.01$ & $0.27 \pm 0.05$ & $0.08 \pm 0.04$ \\
\hline Iso $16: 0$ & $0.10 \pm 0.01$ & $0.11 \pm 0.02$ & $0.42 \pm 0.13$ & $0.05 \pm 0.03$ \\
\hline Anteiso 16:0 & $0.13 \pm 0.03$ & $0.12 \pm 0.02$ & $0.15 \pm 0.12$ & $0.11 \pm 0.03$ \\
\hline$\Sigma$ Branched & $0.39 \pm 0.06$ & $0.39 \pm 0.01$ & $0.94 \pm 0.30$ & $0.32 \pm 0.02$ \\
\hline $16: 1 n-7$ & $42.9 \pm 4.02$ & $41.73 \pm 1.50$ & $38.68 \pm 6.23$ & $45.72 \pm 9.14$ \\
\hline $17: 1 \mathrm{n}-8$ & $2.06 \pm 0.57$ & $2.12 \pm 0.29$ & $0.58 \pm 0.19$ & $1.92 \pm 0.52$ \\
\hline $18: 1 n-9$ & $13.34 \pm 1.88$ & $11.71 \pm 0.98$ & $9.84 \pm 1.68$ & $10.26 \pm 3.61$ \\
\hline $18: 1 n-7$ & $3.55 \pm 0.24$ & $3.79 \pm 0.13$ & $4.17 \pm 0.30$ & $3.66 \pm 0.56$ \\
\hline $20: 1 n-9$ & $0.03 \pm 0.01$ & $0.11 \pm 0.13$ & $0.20 \pm 0.08$ & $0.23 \pm 0.07$ \\
\hline $20: 1 n-7$ & $0.26 \pm 0.05$ & $0.38 \pm 0.22$ & $0.26 \pm 0.07$ & $0.58 \pm 0.12$ \\
\hline $22: 1 n-11$ & $0.24 \pm 0.03$ & $0.43 \pm 0.12$ & $0.12 \pm 0.06$ & $0.02 \pm 0.00$ \\
\hline $22: 1 n-9$ & $0.05 \pm 0.01$ & $0.03 \pm 0.00$ & $0.19 \pm 0.19$ & $0.37 \pm 0.23$ \\
\hline$\Sigma$ Monounsaturated & $62.46 \pm 2.12$ & $60.30 \pm 1.11$ & $54.04 \pm 4.69$ & $62.76 \pm 0.62$ \\
\hline $16: 4 n-3$ & $0.18 \pm 0.03$ & $0.12 \pm 0.1$ & $1.27 \pm 0.65$ & $0.14 \pm 0.01$ \\
\hline $18: 2 n-6$ & $0.90 \pm 0.12$ & $0.63 \pm 0.11$ & $2.62 \pm 0.45$ & $0.89 \pm 0.51$ \\
\hline $18: 3 n-6$ & $0.14 \pm 0.07$ & $0.47 \pm 0.18$ & $0.27 \pm 0.03$ & $0.15 \pm 0.03$ \\
\hline $18: 3 n-3$ & $0.51 \pm 0.10$ & $2.37 \pm 0.58$ & $1.61 \pm 0.69$ & $0.96 \pm 0.01$ \\
\hline $18: 4 n-3$ & $0.86 \pm 0.20$ & $0.58 \pm 0.14$ & $1.74 \pm 0.55$ & $0.82 \pm 0.41$ \\
\hline $20: 2 n-6$ & $0.08 \pm 0.01$ & $0.36 \pm 0.28$ & $0.78 \pm 0.91$ & $0.08 \pm 0.04$ \\
\hline $20: 4 n-6$ & $0.70 \pm 0.14$ & $1.23 \pm 0.46$ & $2.48 \pm 1.42$ & $1.21 \pm 0.43$ \\
\hline $20: 4 n-3$ & $0.44 \pm 0.02$ & $0.56 \pm 0.07$ & $0.39 \pm 0.08$ & $0.58 \pm 0.08$ \\
\hline $20: 5 n-3$ & $10.13 \pm 0.61$ & $10.30 \pm 0.89$ & $10.93 \pm 0.99$ & $10.56 \pm 0.94$ \\
\hline $22: 4 n-6$ & $0.31 \pm 0.07$ & $0.16 \pm 0.01$ & $0.23 \pm 0.08$ & $0.13 \pm 0.06$ \\
\hline $22: 5 n-6$ & $0.16 \pm 0.04$ & $0.09 \pm 0.02$ & $1.03 \pm 0.44$ & $0.14 \pm 0.08$ \\
\hline $22: 5 n-3$ & $0.16 \pm 0.04$ & $0.12 \pm 0.01$ & $0.23 \pm 0.04$ & $0.14 \pm 0.01$ \\
\hline $22: 6 n-3$ & $1.71 \pm 0.15$ & $1.28 \pm 0.13$ & $5.59 \pm 1.52$ & $1.48 \pm 0.52$ \\
\hline$\Sigma$ Polyunsaturated & $16.32 \pm 0.56$ & $18.27 \pm 1.47$ & $29.32 \pm 4.72$ & $17.29 \pm 0.98$ \\
\hline$\Sigma(\mathrm{n}-3)$ & $14.03 \pm 0.48$ & $15.33 \pm 1.88$ & $21.91 \pm 3.17$ & $14.69 \pm 0.97$ \\
\hline$\Sigma(\mathrm{n}-6)$ & $2.29 \pm 0.19$ & $2.95 \pm 0.51$ & $7.42 \pm 1.61$ & $2.60 \pm 0.11$ \\
\hline$(n-3) /(n-6)$ & $6.12 \pm 0.32$ & $5.20 \pm 1.52$ & $2.95 \pm 0.41$ & $5.66 \pm 2.01$ \\
\hline
\end{tabular}



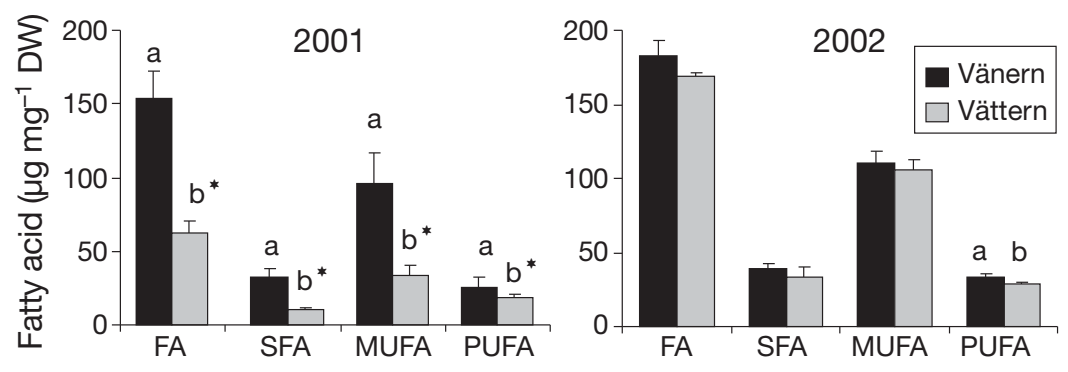

\section{DISCUSSION}

Fig. 6. Monoporeia affinis. Concentrations ( $\mu \mathrm{g} \mathrm{mg}^{-1}$ dry wt) of total fatty acids (FA), saturated fatty acids (SFA), monounsaturated fatty acids (MUFA) and polyunsaturated fatty acids (PUFA) in $M$. affinis collected in Lake Vänern and Lake Vättern in 2001 and 2002. Data are means (+SD) of pooled amphipod samples from 4 stations in each of Lake Vänern and in Lake Vättern. Different letters indicate significant differences $(t$-test, $\mathrm{p}<0.05)$ between lakes. ${ }^{*}$ Significant differences $(t$-test, $\mathrm{p}<0.05)$ between years in that lake

0.0001 and $\mathrm{p}=0.015$, respectively, $\mathrm{df}=8, t$-test; Fig. 6). In Lake Vättern amphipod concentration of palmitoleic acid (16:1n-7), a biomarker for diatoms (Ahlgren 1992), was just one-third of that in Lake Vänern $(\mathrm{p}<0.0001$, df $=8$, $t$-test; Fig. 7). In 2002, the difference between the lakes decreased due to greater increase of lipid concentrations in Lake Vättern amphipods. Lipid concentrations in Lake Vänern amphipods increased just slightly. In 2002, only PUFA differed between lakes ( $p<0.02$, df $=4, t$-test; Fig. 6). The ratios between FAs of the n-3 and n-6 families, regarded as a measure of high-quality food (Goedkoop et al. 2000), were 6.1 and 3.0 in amphipods from Lake Vänern and Lake Vättern in 2001, respectively. In 2002, the ratio increased in Lake Vättern to 5.7, and in Lake Vänern it decreased to 5.2 (Table 2). In Lake Vänern only PUFA differed between years, higher concentrations being recorded in 2002 ( $p=0.018, d f=5, t$-test; Fig. 6).

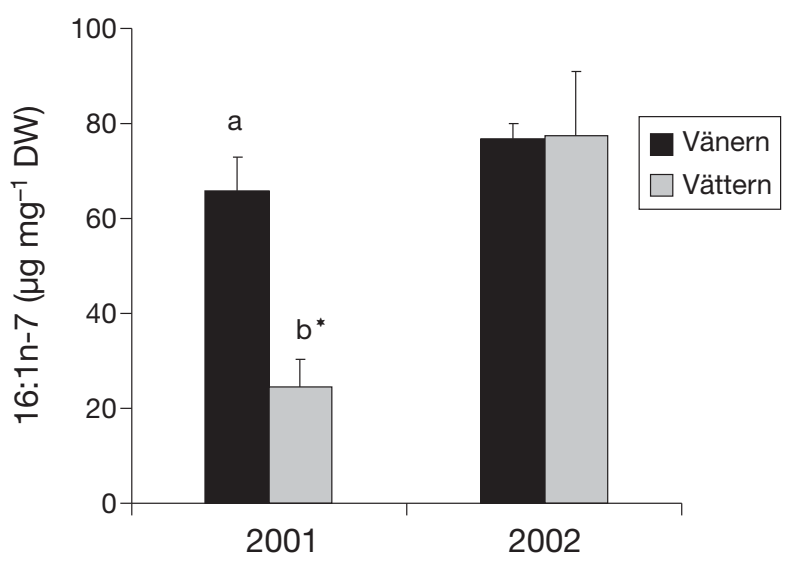

Fig. 7. Monoporeia affinis. Concentrations ( $\mu \mathrm{g} \mathrm{mg}^{-1}$ dry wt) of palmitoleic acid $(16: 1 \mathrm{n}-7)$ in $M$. affinis collected in Lake Vänern and Lake Vättern in 2001 and 2002. Data are means (+SD) of pooled amphipod samples from 4 stations in each of Lake Vänern and Lake Vättern. ${ }^{*}$ Significant differences $(t$-test, $\mathrm{p}<0.05)$ between years in that lake

$$
\text { ated eggs and biovolume of total algae in }
$$
Lake Vättern and fecundity and diatoms in Lake Vänern were recorded. It is possible that food deficiency can explain the increased aberrations due to the ultraoligotrophic status of Lake Vättern and explain the significant correlation between undifferentiated, dead eggs and broods and fecundity in both lakes. A study conducted in the Baltic showed higher percentages of undifferentiated eggs in the oligotrophic Bothnian Bay than in the more eutrophic Bothnian Sea (Sundelin \& Eriksson 1998). Earlier studies in the Baltic have demonstrated a close relationship between fecundity and carbon in primary production (Eriksson Wiklund et al. 2001, www. havet.nu/dokument/Bv2000vitmarla.pdf). A comparison of phytoplankton quantity measured as biovolume $\left(\mathrm{mm}^{3} \mathrm{l}^{-1}\right)$ and production of $\mathrm{chl}$ a showed a difference between lakes, production of diatoms being considerably higher in Lake Vänern during the investigation period (Fig. 3, for detailed data sources see http://info1.ma.slu. se/db.html).

In the field, multiple abiotic and biotic variables act together, and it is difficult to separate the effects of single factors. The same sites with their unique sediment characteristics and depth were studied during several years. Since $\mathrm{pH}$ and oxygen concentrations in bottom waters did not change during the investigation period and low temperatures known to be harmless for Monoporeia affinis reproduction (Eriksson Wiklund \& Sundelin 2001, 2004) were measured, an excellent opportunity to examine the effects of nutrition in terms of food quality and availability was given when the biovolume of diatoms in the spring bloom of 2001 was 3 -fold the average value measured in the last decades. Phytoplankton production in the growth season generally governs the fecundity of females in the first months of the following year (Eriksson Wiklund et al. 2001, www.havet.nu/ dokument/Bv2000vitmarla.pdf). The intermittent feeding pattern of $M$. affinis (see information on feeding strategy in 'Introduction') leads to a spring bloom storage of diatom lipids, later transferred to oocytes and 
used during embryogenesis between November and January. Accordingly, the dramatic increase of mainly diatoms in primary production in 2001 was reflected in a 2-fold increase of fecundity of $M$. affinis in 2002.

Very low lipid concentrations and FA concentrations were recorded in the amphipods sampled in 2001. A minimum value of about $20 \%$ lipids by dry weight has been suggested as necessary for initiating reproduction of Monoporeia affinis (Hill et al. 1992). At most stations in Lake Vättern pre-adult amphipods did not reach this threshold value in January 2001. After spring bloom, however, concentrations probably increased sufficiently for the reproduction process to start in August 2001. Earlier results suggested that amphipods store sufficient reproduction energy from the spring bloom as TAG. Having measured metabolic costs in relation to stored lipid energy, however, Lehtonen (1996) concluded that reserve lipids could cover only 26 to $64 \%$ of the metabolism in females from November to March. More recent data also show that $M$. affinis is dependent on energy during the reproduction period to maintain non-reproductive normal physiological processes as well (Aletjawi \& Leonardsson 2003). During sexual maturation females need lipids for vitellogenesis (synthesis and uptake of yolk protein during oogenesis) when the weight of the ovaries increases 4- to 8-fold. Sufficient nutrients must be accumulated in the egg yolk to allow the normal development of embryos, and dietary requirements of shrimps are generally higher in sexually maturing adults than in non-reproductive adults and juveniles (Harrison 1990, Wouters et al. 2001, Rosa \& Nunes 2003). It is probable that insufficient amounts of storage lipids will influence the viability and development of embryos, due to the demonstrated importance of lipids for vitellogenesis (Mourente \& Rodriguez 1991, Pond et al. 1996). During embryo development UFAs (unsaturated fatty acids) are used to a greater extent than SFA, while MUFAs are utilized to a greater extent than PUFA (Morais et al. 2002, Rosa et al. 2003, 2005).

Very low concentrations of SFA and MUFA were recorded in Lake Vättern amphipods in 2001. Eggs and embryos contain MUFA to a higher extent than adults, since these FAs are necessary as fuels during embryogenesis (Clarke et al. 1990, Rosa \& Nunes 2002, Rosa et al. 2003 , 2005). Malnutrition during the critical oogenesis period could probably result in damage to oocytes, resulting in abnormal development during embryogenesis.

Dead broods probably also reflect food availability, since this variable differs between the lakes. In theory, a combination of stressors may have caused the dead broods and undifferentiated eggs in Lake Vättern. Increased temperatures and oxygen deficiency in bottom water have earlier been reported to induce these types of aberrations in Monoporeia affinis (Eriksson
Wiklund \& Sundelin 2001, 2004). Oxygen concentrations in bottom water were high at Lake Vättern stations and way beyond the level that affects reproduction in M. afffinis (Eriksson Wiklund \& Sundelin 2001, 2004). Temperatures in bottom water during the period showed values known to be harmless for $M$. affinis reproduction, and no relationships were found between reproduction variables and temperature and oxygen levels, so food deficiency is likely to be the major cause of the high frequencies of undifferentiated eggs and dead broods in Lake Vättern. The findings are supported by very low concentrations of lipid and FA concentrations in amphipods collected in Lake Vättern before 2002, significant correlation between fecundity and lipid concentration and significant negative relationship between fecundity and undifferentiated eggs, dead eggs and broods. The linkage to primary production was shown by a strong positive relationship between algal production and fecundity and a negative relationship between algal production and undifferentiated eggs in Lake Vättern. Finally, the ratio between FAs of the n- 3 and n- 6 families, regarded as a measure of high-quality food, increased in amphipods when diatom production and fecundity and embryo aberrations increased. We have no information about FA composition and content in the diet of amphipods, but recent studies on Daphnia magna suggest the n-3 and n-6 families have a great potential to serve as dietary trophic markers (Brett et al. 2006).

A large number of bioassays and field studies have demonstrated a close relationship between contaminant exposure and malformed embryos (Sundelin 1983, Eriksson et al. 1996, Sundelin \& Eriksson 1998), and the variable (malformed embryos) is included in the method (Sundelin et al. 2008) used in the Swedish National Monitoring Programme in order to detect the effects of contaminated sediments. In the present study, no relationship between malformed embryos and food deficiency was recorded, which further underlines the suitability of malformed embryos as a contaminant-sensitive bioindicator. Furthermore, $20 \mathrm{yr}$ of studies have failed to show any relationship between contaminants and undifferentiated eggs, but, in bioassays, these were related instead to increased water temperature before mating and also to oxygen deficiency (Sundelin \& Eriksson 1998, Eriksson Wiklund \& Sundelin 2001, Sundelin et al. 2008).

\section{CONCLUSIONS}

Normally it is very difficult to link biological effects to specific biotic or abiotic parameters in the field, where various stressors act in concert. This study offered an excellent situation to evaluate the influence 
of food availability, since other parameters (temperature, $\mathrm{pH}$ and oxygen concentrations in bottom waters, organic content in sediment and sediment characteristics) showed values known to be harmless and did not significantly differ between the years. In conclusion, the results strongly point to a close relationship between embryo aberrations such as undifferentiated eggs and dead broods and low food resources. MUFA and SFA seem to be important for vitellogenesis and oogenesis and also constitute fuel during Monoporeia affinis embryogenesis, while PUFA seem to have less influence on these processes. The exact nature of these mechanisms, however, is not clearly examined and needs to be further investigated.

Furthermore, we will underline earlier results showing malformed embryos as a suitable contaminant-sensitive bioindicator, while undifferentiated eggs are related to food deficiency and seem to be insensitive to contaminant exposure. Dead eggs and broods show a slightly weaker relationship to food availability, but are also very closely related to hypoxia (Eriksson Wiklund \& Sundelin 2001, 2004), and by using the embryo method (Sundelin et al. 2008) we will have promising possibilities to discriminate between different environmental stressors in the field. However, we have limited information about the synergistic effects of contaminants and malnutrition, as well as of climate stress, a topic important for further studies.

Acknowledgements. This work was financed by the Swedish EPA and Lake Vättern Society for Water Conservation, County Administrative Board. We thank Måns Lindell and Willem Goedkoop for great support during this work, Eva Håkansson and Therese Jacobson assisted in field work. We thank 4 anonymous reviewers for valuable comments on the manuscript. Ingela Björck revised the language. R.R. was funded by the Fundação para a Ciência e Tecnologia (FCT), Portugal.

\section{LITERATURE CITED}

Ahlgren G (1992) Fatty acid content and chemical composition of freshwater microalgae. J Phycol 28:37-50

Aletjawi AA, Leonardsson K (2003) Survival during adverse seasons reveals the size-dependent competitive ability in a deposit-feeding amphipod Monoporeia affinis. Oikos 97: 31-44

Bligh EG, Dyer WJ (1959) A rapid method of total lipid extraction and purification. Can J Biochem Physiol 37:911-917

Boë Chat IG, Adrian R (2006) Evidence for biochemical limitation of population growth and reproduction of the rotifer Keratella quadrata fed with freshwater protists. J Plankton Res 28:1027-1038

Brett MT, Müller-Navarra DC (1997) The role of highly unsaturated fatty acids in aquatic food web processes. Freshw Biol 38:483-499

Brett MT, Müller-Navarra DC, Ballantyne AP, Ravet JL, Goldman CR (2006) Daphnia fatty acid composition reflects that of their diet. Limnol Oceanogr 51:2428-2437

> Clarke A, Brown JH, Holmes LJ (1990) The biochemical composition of eggs from Macrobrachium resenbergii in rela- tion to embryonic development. Comp Biochem Physiol B 96:505-511

Cohen Z, Vonshak A, Richmond A (1988) Effect of environmental conditions on fatty-acid composition of the red alga Porphyridium cruentum-correlation to growth-rate. J Phycol 24:328-332

Cruz-Rivera E, Hay ME (2000) Can quantity replace quality? Food choice, compensatory feeding, and fitness of marine mesograzers. Ecology 81:201-219

Czeczuga BM, Kozlowska M, Kiziewics B (2003) Effect of various types of phytoplankton on fertility, egg size and duration of postembryonic growth of a few plankton representatives of Cladocera (Crustacea). P J Environ Stud 12: 545-555

Dermott R, Corning K (1988) Seasonal ingestion rates of Pontoporeia hoyi (Amphipoda) in Lake Ontario. Can J Fish Aquat Sci 45:1886-1895

Ederington MC, McManus GB, Harvey HR (1995) Trophic transfer of fatty acids, sterols, and a triterpenoid alcohol between bacteria, a ciliate, and the copepod Acartia tonsa. Limnol Oceanogr 40:860-867

Eriksson AK, Sundelin B, Broman D, Näf C (1996) Effects on Monoporeia affinis of HPLC-fractionated extracts of bottom sediments from a pulp mill recipient. In: Servos MR, Munkittrick KR, Carey JH, Van der Kraak G (eds) Environmental fate and effects of pulp and paper mill effluents. St Lucie Press, Delray Beach, FL, p 69-78

Eriksson Wiklund AK, Sundelin B (2001) Impaired reproduction in the amphipods Monoporeia affinis and Pontoporeia femorata as a result of moderate hypoxia and increased temperature. Mar Ecol Prog Ser 222:131-141

> Eriksson Wiklund AK, Sundelin B (2004) Biomarker sensitivity to temperature and hypoxia-a seven year field study. Mar Ecol Prog Ser 274:209-214

Eriksson Wiklund AK, Håkansson E, Sahl P, Sundelin B (2001) Vitmärlans embryonalutveckling. In: Wiklund K (ed) Bottniska Viken 2000, årsrapport från den marina miljöövervakningen. Umeå Marine Research Center, Umeå, p 15-16 (Swedish report, English summary)

Fitzgerald SA, Gardner WS (1993) An algal carbon budget for pelagic-benthic coupling in Lake Michigan. Limnol Oceanogr 38:547-560

Gardner WS, Quigley MA, Fahnenstiel GL, Scavia D, Frez WA (1990) Pontoporeia hoyi-a direct trophic link between spring diatoms and fish in Lake Michigan. In: Tiller MM, Serruya C (eds) Large lakes - ecological structure and function. Springer, New York, p 632-644

Ghioni C, Bell JG, Sargent JR (1996) Polyunsaturated fatty acids in neutral lipids and phospholipids of some freshwater insects. Comp Biochem Physiol B 114:161-170

Glazier DS (2000) Is fatter fitter? Oecologia 122:335-345

Goedkoop W, Johnson RK (1994) Exploitation of sediment bacterial carbon by juveniles of the amphipod Monoporeia affinis. Freshw Biol 32:553-563

Goedkoop W, Johnson RK (1996) Pelagic-benthic coupling: profundal benthic community response to spring diatom deposition in mesotrophic Lake Erken. Limnol Oceanogr 41:636-647

> Goedkoop W, Johnson RK (2001) Factors affecting population fluctuations of the glacial relict amphipod Monoporeia affinis in Sweden's largest lakes. Ambio 30:552-559

Goedkoop W, Sonesten L, Ahlgren G, Boberg M (2000) Fatty acids in profundal benthic invertebrates and their major food resources in Lake Erken-seasonal variation and trophic indications. Can J Fish Aquat Sci 57:2267-2279

Guiguer KRA, Barton DR (2002) The trophic role of Diporeia (Amphipoda) in Colpoys Bay (Georgian Bay) benthic food 
web: a stable isotope approach. J Gt Lakes Res 28: 228-239

Hanson BJ, Cummins KW, Cargill AS, Lowry RR (1985) Lipid content, fatty acid composition and the effect of diet on fats of aquatic insects. Comp Biochem Physiol B 80:257-276

Harrison KE (1990) The role of nutrition in maturation, reproduction and embryonic development of decapod crustaceans: a review. J Shellfish Res 9:1-28

Herring JP (1973) Depth distribution of the carotenoid pigments and lipids of some oceanic animals. 2. Decapod crustaceans. J Mar Biol Assoc UK 53:539-562

Hill C, Quigley MA, Cavaletto JF, Gordon W (1992) Seasonal changes in lipid content and composition in the benthic amphipods Monoporeia affinis and Pontoporeia femorata. Limnol Oceanogr 37:1280-1289

> Höglander H, Larsson U, Hajdu S (2004) Vertical distribution and settling of spring phytoplankton in the offshore NW Baltic Sea proper. Mar Ecol Prog Ser 283:15-27

> Lehtonen KK (1994) Metabolic effects of short-term starvation on the benthic amphipod Pontoporeia affinis (Lindström) from the northern Baltic Sea. J Exp Mar Biol Ecol 176: 269-283

Lehtonen KK (1996) Ecophysiology of the benthic amphipod Monoporeia affinis in an open-sea area of the northern Baltic Sea: seasonal variations in oxygen consumption and ammonia excretion. Mar Biol 126:645-654

Lepage G, Roy CC (1986) Direct transesterification of all classes of lipids in a one-step reaction. J Lipid Res 27:114-119

Lopez G, Elmgren R (1989) Feeding depths and organic absorption for the deposit-feeding bethic amphipods Pontoporeia affinis and Pontoporeia femorata. Limnol Oceanogr 34:982-991

Marzolf RG (1975) Vertical migration of Pontoporeia affinis (Amphipoda) in Lake Michigan, Vol 13. Great Lakes Research Division, The University of Michigan, Ann Arbor, p 133-140

> Morais S, Narciso L, Calado R, Nunes ML, Rosa R (2002) Lipid dynamics during the embryonic development of Plesionika martia martia (Decapoda; Pandalidae), Palaemion serratus and P. elegans (Decapoda; Palaemonidae): relation to metabolic consumption. Mar Ecol Prog Ser 242: 195-204

Mourente G, Rodriguez A (1991) Variation in the lipid content of wild-caught females of the marine shrimp Penaeus kerathurus during sexual maturation. Mar Biol 110:21-28

Müller-Navarra DC, Brett MT, Liston AM, Goldman CR (2000) A highly unsaturated fatty acid predicts carbon transfer between primary producers and consumers. Nature 403:74-77

Nordbäck J, Lundberg E, Christie WW (1998) Separation of lipid classes from marine particulate material by HPLC on a polyvinyl alcohol-bonded stationary phase using dualchannel evaporative light-scattering detection. Mar Chem 60:165-175

> Norsker NH, Støttrup JG (1994) The importance of dietary HUFAs for fecundity and HUFA content in the harpacticoid Thisbe holothuriae. Aquaculture 125:155-166

> Ólafsson E, Elmgren R (1997) Seasonal dynamics of sublittoral meiobenthos in relation to phytoplankton sedimentation in the Baltic Sea. Estuar Coast Shelf Sci 45:149-164

Olli K, Heiskanen AS, Lohikari K (1998) Vertical migration of autotrophic micro-organisms during a vernal bloom at the coastal Baltic Sea-coexistence through niche separation. Hydrobiologia 363:179-189

> Pond D, Harris R, Head R, Harbour D (1996) Environmental

Editorial responsibility: Angus Atkinson,

Cambridge, UK and nutritional factors determining seasonal variability in the fecundity and egg viability of Calanus helgolandicus in coastal waters off Plymouth, UK. Mar Ecol Prog Ser 143: 45-63

Quigley MA (1988) Gut fullness of deposit-feeding amphipod, Pontoporeia hoyi in southeastern Lake Michigan. J Gt Lakes Res 14:178-187

Rosa R, Nunes ML (2002) Biological changes during the reproductive cycle of the deep-sea decapod Nephrops norvegicus on the south coast of Portugal. Mar Biol 141:1001-1009

> Rosa R, Nunes ML (2003) Tissue biochemical composition in relation to the reproductive cycle of the deep-sea decapod, Aristeus antennatus in the Portuguese south coast. J Mar Biol Assoc UK 83:963-970

> Rosa R, Morais S, Calado R, Narciso L, Nunes ML (2003) Biochemical changes during the embryonic development of Norway lobster, Nephrops norvegicus. Aquaculture 221: 507-522

Rosa R, Calado R, Andrade AM, Narciso L, Nunes ML (2005) Changes in amino acids and lipids during embryogenesis of European lobster, Homarus gammarus (Crustacea: Decapoda). Comp Biochem Physiol B 140:241-249

> Rosa R, Calado R, Narciso L, Nunes ML (2007) Embryogenesis of decapod crustaceans with different life history traits, feeding ecologies and habitats: a fatty acid approach. Mar Biol 151:935-947

Schmidt K, Kahler P, von Bodungen B (1998) Copepod egg production rates in the Pomeranian Bay (southern Baltic Sea) as a function of phytoplankton abundance and taxonomic composition. Mar Ecol Prog Ser 174:183-195

Sundelin B (1983) Effects of cadmium on Pontoporeia affinis (Crustacea: Amphipoda) in laboratory soft-bottom microcosms. Mar Biol 74:203-212

Sundelin B, Eriksson AK (1998) Malformations in embryos of the deposit-feeding amphipod Monoporeia affinis in the Baltic Sea. Mar Ecol Prog Ser 171:165-180

Sundelin B, Ryk C, Malmberg G (2000) Effects on the sexual maturation of the sediment-living amphipod Monoporeia affinis. Environ Toxicol 15:518-526

Sundelin B, Eriksson Wiklund AK, Ford A (2008) Biological effects of contaminants: The use of embryo aberrations in amphipod crustaceans for measuring effects of environmental stressors. ICES Tech Mar Environ Sci 41

van de Bund WJ, Ólafsson E, Modig H, Elmgren R (2001) Effects of the coexisting Baltic amphipods Monoporeia affinis and Pontoporeia femorata on the fate of a simulated spring diatom bloom. Mar Ecol Prog Ser 212:107-115

Vanderploeg HA, Liebig JR, Gluck AA (1996) Evaluation of different phytoplankton for supporting development of zebra mussel larvae (Dreissena polymorpha): the importance of size and polyunsaturated fatty acid content. J Gt Lakes Res 22:36-45

Vargas CA, Escribano R, Poulet S (2006) Phytoplankton food quality determines time windows for successful zooplankton reproductive pulses. Ecology 87:2992-2999

von Elert E, Wolffrom T (2001) Supplementation of cyanobacterial food with polyunsaturated fatty acids does not improve growth of Daphnia. Limnol Oceanogr 46:1552-1558

> Wouters R, Molina C, Lavens P, Calderon J (2001) Lipid composition and vitamin content of wild female Litopenaeus vannamei in different stages of sexual maturation. Aquaculture 198:307-323

- Wu RSS (2002) Hypoxia: from molecular responses to ecosystem responses. Mar Pollut Bull 45:35-45

Submitted: December 17, 2007; Accepted: April 15, 2008

Proofs received from author(s): May 28, 2008 